\title{
Marta Gliniecka
}

Akademia Pomorska w Słupsku

\section{PROFIL NA FACEBOOKU - AWATAR, WIRTUALNA MASKA CZY OBRAZ SIEBIE? O KONSTRUOWANIU TOŻSAMOŚCI INTERNETOWEJ}

\author{
Abstract \\ FACEBOOK PROFILE - AVATAR, VIRTUAL MASK OR SELF-IMAGE? \\ ABOUT CREATING AN ONLINE IDENTITY
}

People from the beginning of history assumed the mask. In tribal cultures, they were accompanied by magical rituals and rites of passage. Currently masks are attributes of superheroes. Today we assume virtual mask. We're trying to create the perfect look. For this purpose, we use online games, and social media, especially Facebook web portal, called the great book of faces. The article presents the results of research (content analysis, focus groups) conducted among students on Facebook and avatars.

Key words: social media, avatar, virtual mask, online identity, visual culture

\section{Wprowadzenie}

W dzisiejszych czasach, w dobie kultury wizualnej sztuka autoprezentacji zaczyna mieć coraz większe znaczenie. Człowiek nieustannie kreuje swój wizerunek za pomocą nowych technologii, w tym serwisów społecznościowych. Młodzi ludzie każdego dnia publikują zdjęcia i nagrania wideo, które przedstawiają ich życie codzienne. Zakładają wirtualne maski i odgrywają swoje role, bo wiedzą, że po drugiej stronie ekranu setki odbiorców śledzą każdy ich ruch. Jak trafnie zauważa Zygmunt Bauman, „liczne kontakty pomagają także uaktualniać szybko własny wizerunek lub choćby zmieniać w nim w porę rozkład akcentów” ${ }^{1}$. Zdaniem badacza

1 Z. Bauman, 44 listy ze świata płynnej nowoczesności, Wydawnictwo Literackie, Kraków 2011, s. 29. 
dzięki rozbudowanej sieci znajomych młodzi wiedzą to, czego aktualnie potrzebują; znają tytuły muzycznych hitów, wyczyny celebrytów czy popularne festiwale i imprezy. W dobie płynnej nowoczesności tożsamość stała się czymś kruchym i podatnym na zmiany. $\mathrm{W}$ przeciwieństwie do swoich przodków młode pokolenie dąży „do możliwości zmiany tożsamości i sieci kontaktów”.

Celem artykułu jest refleksja nad wizualnym konstruowaniem tożsamości w kontekście wykorzystania mediów społecznych na przykładzie portalu Facebook. Główne problemy badawcze dotyczyć będą między innymi tego, w jaki sposób młodzi ludzie tworzą wizualne reprezentacje swojej osoby w przestrzeni sieci, jaki jest ich stosunek do awatarów oraz dlaczego zakładają wirtualne maski.

\section{Od masek archaicznych po maski internetowe}

Człowiek od zawsze miał potrzebę zakładania masek. Etymologia tego słowa $\mathrm{z}$ jednej strony wskazuje na związek maski z osobą (łac. persona), a z drugiej - ze światem przodków. Warto zauważyć, że pierwotna forma lārua, lārva oznaczała maskę i jednocześnie ducha ${ }^{3}$. W kulturach plemiennych znane były maski wodza, czarownika, szamana. To dzięki nim mogło dojść do przeobrażenia. Jak pisał Roger Caillois, maski przeistaczały „ofiarników w bóstwa, zwierzęta - w przodków, we wszelkiego rodzaju siły nadprzyrodzone"4. Były nierozerwalnie związane ze sferą sacrum. Pojawiały się przy okazji rozmaitych uroczystości i ceremonii, w tym obrzędów o charakterze religijno-magicznym. Jak przekonuje Asa Boholm ${ }^{5}$, ich zadaniem było stwarzanie przestrzeni komunikacji ze zmarłymi, bogami, jak i z samym sobą. Maski pełniły także ważną funkcję w czasie rytuałów przejścia, w trakcie których młody człowiek przekraczał próg dorosłości, otrzymując nową rolę społeczną. W kulturach plemiennych tożsamość była nadawana społecznie, obecnie młody człowiek staje wobec wyboru wartości, które będzie realizował w swoim życiu. Jak zauważa Katarzyna Joniec-Bubula ${ }^{6}$, przejście od tożsamości przejętej do tożsamości tworzonej nastąpiło w wyniku rewolucji przemysłowej oraz przemian społeczno-kulturowych w postaci demokratyzacji życia i postępu technologicznego.

2 Tamże.

3 A. Brückner, Stownik etymologiczny języka polskiego, Wiedza Powszechna, Warszawa 2000, s. 324 .

${ }^{4}$ R. Caillois, Maska i trans, [w:] M. Janion, S. Rosiek (red.), Maski. Transgresje, t. IV, Wydawnictwo Morskie, Gdańsk 1986, s. 73.

${ }^{5}$ A. Boholm, Weneckie widowiska karnawałowe w maskach, przeł. J. Jaworska, [w:] A. Chałupnik, W. Dudzik, M. Kanabrodzki i in. (red.), Antropologia widowisk: zagadnienia i wybór tekstów, Wydawnictwa Uniwersytetu Warszawskiego, Warszawa 2005, s. 658.

${ }^{6} \mathrm{~K}$. Joniec-Bubula, Rola rytuałów przejścia w tworzeniu się tożsamości w okresie dorastania, [w:] A. Gałdowa (red.), Tożsamość człowieka, Wydawnictwo Uniwersytetu Jagiellońskiego, Kraków 2000, s. 167. 
Współczesny człowiek zyskał swobodę wyboru nie tylko tego, kim chce być, ale również tego, jak będzie postrzegany przez innych. Może przybierać różne maski.

W świecie antycznym maski miały wyeksponować określone cechy bohatera, ale też wzmocnić głos aktora na scenie. W średniowieczu zakładanie masek wiązało się z okresem przejściowego chaosu oraz zawieszeniem tymczasowego porządku, co następowało chociażby w czasie karnawału weneckiego. Jak podkreśla Caillois, obecnie przetrwały tylko dwie formy: „mała czarna maseczka na oczy oraz groteskowa maska karnawałowa"'.

Dzisiaj maski stają się atrybutami superbohaterów i złoczyńców. Noszą je zarówno Batman, Zorro, Spider-Man, jak też Lord Vader czy psychopatyczny bohater filmu Piła. Dzięki temu mogą oni pozostać anonimowi. Zadaniem masek staje się utrudnienie identyfikacji postaci. Coraz częściej mówi się o maskowaniu w kontekście pejoratywnym. Maskowanie to ukrywanie swoich intencji, zasłanianie prawdziwego oblicza. Warto jednak zauważyć, że maska może jednocześnie zasłaniać, jak i odsłaniać prawdę o człowieku. Jak słusznie podkreśla Claude Lévi-Strauss, „sens maski nie tkwi w tym, co ona przedstawia, ale w tym, co przeobraża"8.

Anna Tylikowska zwraca uwagę, że obecnie mamy do czynienia z e-maskaradą. „Nie tylko poprawiamy swoje e-wizerunki w programach graficznych (...). Przypisujemy sobie cechy, o których w realu moglibyśmy tylko marzyć. Nadajemy sobie nowe imiona, podkreślając radykalną zmianę tożsamości" ${ }^{\prime 9}$. Współczesne odmiany maski to zarówno makijaż (tzw. make-up), korekta wizerunku w Photoshopie, jak i konstruowanie różnego rodzaju awatarów, rozumianych jako wizualne reprezentacje osoby w przestrzeni Internetu. Jak zauważa Magdalena Szpunar ${ }^{10}$, za sprawą technologii współczesny człowiek nieustannie wystawia swoje życie na pokaz, ale nie staje się przez to bardziej autentyczny. Z obawy przed zranieniem woli ukrywać swoje prawdziwe oblicze za zasłoną. Tworzy tożsamość internetową, która stanowi wirtualny odpowiednik jego autodefinicji, zbiór wyobrażeń na własny temat ${ }^{11}$.

Zdaniem Jolande Jacobi w ciągu ostatniego stulecia „pragnienie mimikry, zniknięcia w masce, nałożenia maski, stało się coraz bardziej powszechne, nieodparte, a nawet zupełnie świadome"12. Świadczy o tym popularność zjawiska cosplay (ang. costume - strój, play - zabawa), które polega na przebieraniu się za bohaterów $\mathrm{z}$ popkultury. Istotne jest reprodukowanie istniejących form oraz jak najdokładniejsze odwzorowanie postaci (strój, poza, gesty). Wielu młodych ludzi przebiera

7 R. Caillois, dz. cyt., s. 160.

${ }^{8}$ C. Lévi-Strauss, Maska nie istnieje sama w sobie, [w:] M. Janion, S. Rosiek (red.), Maski. Transgresje, t. IV, s. 72.

9 A. Tylikowska, E-maskacja, „Ja My Oni” - Poradnik Psychologiczny „Polityki” 2014, t. 16, nr 9, s. 16.

${ }_{10}$ M. Szpunar, Kultura cyfrowego narcyzmu, Wydawnictwo AGH, Kraków 2016, s. 157.

${ }^{11}$ M. Szpunar, Internet jako pole poszukiwania i konstruowania własnej tożsamości, [w:] E. Hałas, K. Konecki (red.), Konstruowanie jaźni i społeczeństwa. Europejskie warianty interakcjonizmu symbolicznego, Scholar, Warszawa 2005, s. 378.

12 A. Tylikowska, dz. cyt., s. 16. 
się za postaci znane z mangi czy komiksów. Spotykają się na konwentach i organizują sobie sesje zdjęciowe. W korowodzie przebierańców można spotkać Batmana, Jokera, Supermana czy Wonder Woman. Małgorzata Bogunia-Borowska ${ }^{13}$ traktuje to zjawisko jako szerszy trend, który wpisuje się w kulturę imitacji. Jej zdaniem współczesny człowiek pragnie nie tylko stać się wierną kopią oryginału, lecz chce być od niego lepszy. Dąży więc do perfekcji w naśladownictwie.

\section{2. Życie w kulturze symulacji - o fenomenie awatarów}

Można odnieść wrażenie, że współczesny człowiek żyje w kulturze symulacji. Jean Baudrillard ${ }^{14}$ twierdzi, że w epoce ponowoczesnej dominuje znak, symulacje i złudzenia. Badacze są zgodni co do tego, że granica między światem realnym i wirtualnym często ulega zatarciu. „Gra w życie z dystansu” - jak to określa Maryla Hopfinger ${ }^{15}$ - toczy się także na portalach internetowych. W przestrzeni sieci możemy bowiem eksperymentować z tożsamością - od fabularnych gier internetowych po portale społecznościowe. Sherry Turkle mówi o pokoleniu tamagotchi, które w latach 90. zamiast bawić się z prawdziwym psem czy kotem symulowało opiekę nad elektronicznym zwierzakiem. Zdaniem badaczki Internet „otwiera wiele nowych form przestrzeni. Na jednym końcu spektrum sytuują się blogi (...). Tam mamy być sobą. Na drugim końcu znajdują się światy, w których konstruujemy awatary - od gier po społeczności wirtualne"16.

Wystarczy wspomnieć znaną platformę Second Life, którą Paul Levinson ${ }^{17}$ zalicza do nowych nowych mediów. Ten trójwymiarowy, wirtualny świat został stworzony przez Philipa Rosedale'a w 2003 roku. Paradoksalnie powstał po to, aby zacieśniać więzi między ludźmi. Tymczasem przebywanie w nim często prowadzi do izolacji. Second Life symuluje świat realny, dążąc do odwzorowania znanych struktur społecznych. Można tam spotkać galerie handlowe, muzea, siedziby uniwersytetów, biblioteki, sale koncertowe, a nawet kościoły.

Substytutem internauty staje się awatar, który może być przez niego dowolnie wykreowany. $\mathrm{W}$ ten sposób człowiek może swobodnie poruszać się w świecie wirtualnym, uwalniając się od ograniczeń świata fizycznego. Jak zauważa Maryla

${ }^{13}$ Wypowiedź pochodzi z nagrania konferencji „Sztuka/Globalizacja”, która odbyła się 11.10.2014 w Białymstoku z udziałem prof. M. Boguni-Borowskiej. Badaczka wygłosiła referat pt. „Zjawisko Cosplay - costume players - bunt wobec systemu społecznego, forma sztuki czy globalny język komunikacji?”, https://www.youtube.com/watch?v=46Bgd5VxaDg (dostęp: 2.06.2015).

${ }_{14}$ J. Baudrillard, Fotografia, czyli świethy zapis, [w:] M. Boguna-Borowska, P. Sztompka (red.), Fotospołeczeństwo. Antologia tekstów z socjologii wizualnej, Znak, Kraków 2012, s. 386.

${ }_{15}$ M. Hopfinger, Literatura i media po 1989 roku, Oficyna Naukowa, Warszawa 2004, s. 272.

16 S. Turkle, Samotni razem. Dlaczego oczekujemy więcej od zdobyczy techniki, a mniej od siebie nawzajem, przeł. M. Cierpisz, Wydawnictwo Uniwersytetu Jagiellońskiego, Kraków 2013, s. 259.

17 P. Levinson, Nowe nowe media, WAM, Kraków 2010, s. 223. 
Hopfinger ${ }^{18}$, „uczestnik Second Life może dowolnie kierować swoim postępowaniem, angażować się w wybrane role, sprawdzać się w najrozmaitszych sytuacjach". Przykładowo jeden z badaczy nowych mediów - Paul Levinson - postanowił założyć w Second Life wirtualną księgarnię, w której sprzedawał swoje książki. Jak wspomina: „Pewnej nocy mój awatar stał przy wejściu do Soft Edge Book Shop. Inny awatar przechodził akurat ulicą i przystanął, by przyjrzeć się okładce książki (...). Porozmawialiśmy o mojej powieści kilka minut, po czym klient kliknął w link odsyłający do witryny Amazon i kupił ją (...). Cała ta sytuacja wydawała się niezwykle podobna do przebywania w prawdziwej księgarni. Wydawało mi się nawet, że pod palcami czuję fakturę przewracanych kartek” ${ }^{19}$. Samo słowo „awatar” oznacza wcielenie bóstwa. W tym kontekście ciekawa wydaje się refleksja Michała Ostrowickiego, który pisał o „elektronicznej inkarnacji”"20, rozumianej jako pełne utożsamienie się człowieka ze swoim awatarem, a więc postacią przebywającą w sieci. Zdaniem badacza może to wzbogacać codzienne doświadczenia jednostki.

Wydaje się, że podobna sytuacja zachodzi w popularnej grze fabularnej The Sims, która powstała w 2000 roku. Warto zauważyć, że gra rozeszła się w 100 milionach egzemplarzy i została przetłumaczona aż na 20 języków. Być może dlatego w 2002 roku pojawiła się także sieciowa wersja gry - The Sims Online. Tam również internauci mogą samodzielnie konstruować swoje awatary, decydując o ich wyglądzie i cechach osobowości. Mogą nawiązywać relacje z innymi, organizując warunki życia Simów według swoich wyobrażeń. Jak słusznie zauważa badaczka kultury multimedialnej Maryla Hopfinger ${ }^{21}$, gra stanowi symulator codzienności, ale może też być „laboratorium prawdziwego życia”.

Kiedy w czasie dyskusji grupowej prowadzonej w ramach własnych badań zapytałam studentów o fenomen popularności gry The Sims, okazało się, że budzi ona spore emocje nie tylko wśród młodzieży, ale także wśród dorosłych. Największy entuzjazm wzbudza możliwość konstruowania awatarów (wybór wzrostu, koloru oczu, stroju, ale też płci postaci). Gdy zapytałam uczestników o to, co wybraliby na swojego awatara na blogu internetowym lub portalu społecznościowych, jedna ze studentek - pochodząca z Wietnamu, powiedziała, że na pewno nie byłaby to osoba, bo to banalne. Jej zdaniem przedstawienia ze świata natury „pokazują wnętrze człowieka. Ktoś może mieć ducha lwa albo być tak delikatny jak kwiat lotosu, czy tak niesamowicie piękny jak motyl (...). To spojrzenie w głąb siebie”. Co ciekawe, potwierdzają to badania Aleksandry Przegalińskiej ${ }^{22}$, która postanowiła sprawdzić, czym różnią się awatary wybierane przez przedstawicieli kultury

${ }_{18}$ M. Hopfinger, dz. cyt., s. 277.

19 P. Levinson, dz. cyt., s. 224.

${ }^{20}$ M. Ostrowicki, Tożsamość człowieka w środowisku elektronicznym, „Kwartalnik Filmowy” 2008, nr 62-63, s. 149.

${ }^{21}$ M. Hopfinger, dz. cyt., s. 274.

${ }^{22}$ J. Drosio-Czaplińska, Barbie versus czajnik, „Ja My Oni”. Co komputer zrobił nam z głową? Poradnik Psychologiczny „Polityki” 2014, t. 16, nr 9, s. 18. 
Wschodu i Zachodu. Okazało się, że Azjaci częściej wybierają zwierzęta, kwiaty lub zjawiska atmosferyczne. Z kolei Amerykanie chętniej eksponują swoją cielesność (biust, umięśniona sylwetka, zarost). Wynika to $\mathrm{z}$ różnego sposobu postrzegania człowieka oraz jego relacji ze światem. W kulturze Zachodu dominuje indywidualizacja (kult jednostki, doskonalenie wyglądu). Z kolei na Wschodzie panuje orientacja kolektywistyczna, nastawiona na interesy wspólnoty. Człowiek jest tam postrzegany bardziej jako byt energetyczno-duchowy, ciało jest natomiast jedynie formą przejściową. Jak podkreśla Krzysztof Gawlikowski, w kulturze Wschodu „ideałem jest rozszerzanie swojego ja na wspólnotę, ludzkość, zwierzęta, rośliny, kosmos"23.

Popularność The Sims nie ogranicza się jednak wyłącznie do tworzenia awatarów. Gra umożliwia budowanie nowych światów, projektowanie wnętrz. Pozwala wyznaczać ścieżkę rozwoju zawodowego bohaterów, dzięki czemu zmienia się ich status. Stwarza także możliwości odgrywania wielu ról jednocześnie (matki, dziecka, ojca). Zakłada bowiem tworzenie całych rodzin oraz organizowanie środowiska ich życia. The Sims umożliwia również projektowanie własnych cech na tworzone postaci. Zaciekawiło mnie, że część studentek przyznała, iż w świecie wirtualnym chętnie wciela się w męskich bohaterów. Ich wybory podyktowane były chęcią zaimponowania środowisku graczy. Jak same przyznały, w obawie przed stereotypowym traktowaniem wybierały bohatera męskiego, aby być traktowane na równi z pozostałymi uczestnikami gry. Pokazuje to, że w środowisku sieciowym dochodzi do odwzorowania wszelkich aspektów rzeczywistości, włącznie z uprzedzeniami. Najbardziej interesujące były wypowiedzi dotyczące poczucia sprawstwa. Niemal wszystkie osoby zgromadzone na sali przyznały, że lubią grać $\mathrm{w}$ The Sims, ponieważ daje im to poczucie kontroli nad życiem Simów, a niekiedy wręcz władzy. Mogą bowiem decydować o życiu swoich bohaterów, jak i o rodzaju śmierci, która ich spotka.

Sherry Turkle zwraca uwagę, że eksperymentujemy z tożsamością nie tylko w środowisku gier sieciowych, ale też „na portalach społecznościowych, gdzie profile stają się swoistymi awatarami - manifestem na temat tego, kim jesteśmy i kim chcielibyśmy być" 24 . Z badań etnograficznych Turkle prowadzonych wśród młodzieży wynika, że niektórzy uczniowie szkół średnich traktują swój profil na Facebooku jako rodzaj awatara ${ }^{25}$. To kolejna próba tworzenia własnej tożsamości, która jest „refleksyjnym projektem”26.

23 Tamże.

24 S. Turkle, dz. cyt., s. 225-226.

25 Tamże.

26 A. Giddens, Nowoczesność i tożsamość. „Ja” i społeczeństwo w epoce późnej nowoczesności, Wydawnictwo Naukowe PWN, Warszawa 2006, s. 292. 


\section{Profil na Facebooku, czyli tożsamość utkana z fragmentów}

Część socjologów i antropologów kultury (Wojciech Burszta, Zygmunt Bauman, Małgorzata Jacyno) uważa, że współczesna tożsamość jest rozproszona i fragmentaryczna ${ }^{27}$. Pojawia się pytanie, na ile media cyfrowe tworzą środowisko przyjazne dla bycia sobą, a na ile sprzyjają zakładaniu wirtualnych masek? Wydaje się, że w Internecie każdy przynajmniej raz udawał kogoś, kim nie jest. Philip Zimbardo ${ }^{28}$ przekonuje, że zjawisko alternatywnej tożsamości nie jest niczym nowym. Znane są słynne historie szpiegów, którzy byli zmuszeni prowadzić podwójne życie. Anonimowość Internetu może jednak sprzyjać podejmowaniu zachowań ryzykownych, na które nie odważylibyśmy się w świecie realnym. Co ciekawe, z badań Łukasza Rogowskiego wynika, że „strony internetowe są prezentacją uformowanych i jednoznacznych osobowości, aniżeli dowodem na zwielokrotnienie tożsamości w sieci”29.

Nowe technologie, określane mianem „archiwizatorów zdarzen’”30, sprzyjają „narratywizacji jaźni rozumianej jako relacjonowanie fali przepływających przez jednostkę doznań"31. Młodzi ludzie nieustannie zdają relację ze swojego życia. Dokumentują niemal każdy aspekt swojej codzienności, od przebudzenia po zjedzenie śniadania czy wyprawę na zakupy. Dawniej człowiek uwieczniał na fotografii tylko najważniejsze momenty swojego życia, szczególnie te, które napełniały go dumą (ukończenie szkoły, narodziny dziecka). Dzisiaj błahe, codzienne sytuacje urastają do rangi nadzwyczajnych osiągnięć. Małgorzata Jacyno ${ }^{32}$ zwraca uwagę na to, że współczesny człowiek konstruuje swoją tożsamość z ,jakości doznaniowych", takich jak: przeczytana książka, dobry film, słuchanie muzyki czy egzotyczna podróż. Powołując się na Jeana-Claude’a Kaufmanna, badaczka dochodzi do wniosku, że coraz częściej próbujemy nadać „jednorazowym opakowaniom” tożsamości jakąś materialną postać. Mogą to być zarówno fotografie, nagrania wideo, jak też motta i cytaty, które mają wyrażać cząstkową prawdę o nas samych.

$\mathrm{W}$ ten sposób rodzi się tożsamość utkana $\mathrm{z}$ fragmentów, która przestaje być spójną opowieścią o swoim życiu. Niesie to różne zagrożenia. Jak zauważa Monika Jaworska-Witkowska: „fragment zawsze chce wychodzić poza siebie, szuka miejsca, w którym byłby jakoś odniesiony. Fragment bez przekraczającej go całości sam

27 Por. W.J. Burszta, Tożsamość narracyjna $w$ dobie ekranu, [w:] W. Bolecki, R. Nycz (red.), Narracja i tożsamość. Narracje w kulturze, Instytut Badań Literackich PAN, Warszawa 2004, s. 37.

${ }_{28}$ Wypowiedź pochodzi z audycji PWN Tożsamość w Internecie, zapis rozmowy M. Stolarskiego z P. Zimbardo, https://www.youtube.com/watch?v=o_1aZ22Q5LI (dostęp: 3.05.2015).

${ }_{29}$ Ł. Rogowski, Wizualne kształtowanie tożsamości internetowej, http://www.spoleczna.psychologia.pl/lukasz_Rogowski_-_Wizualne_ksztaltowanie_tozsamosci_internetowej.doc (dostęp: 4.05.2015).

${ }^{30}$ S. Turkle, dz. cyt., s. 357.

${ }^{31}$ M. Jacyno, Technologie cyfrowe a techniki self, [w:] M. Filiciak, M. Danielewicz, M. Halawa $\mathrm{i}$ in. (red.), Młodzi i media. Nowe media a uczestnictwo $w$ kulturze, SWPS, Warszawa 2010, s. 31.

32 Tamże, s. 77. 
jest całością, co jest sprzeczne z jego interesem poznawczym, gdyż gubimy wówczas jego obietnicę odsyłającą poza i wbrew temu, z czego się wyrywa" ${ }^{33}$. Portale społecznościowe typu Facebook nieustannie zachęcają nas do tworzenia obrazu siebie ze znalezionych w sieci fragmentów. Z jednej strony stają się „forami dla ekspresji” użytkowników ${ }^{34}$, a z drugiej stanowią „medialne terytoria estetyczne” ${ }^{35}$. To przestrzeń, w której młodzi ludzie mogą tworzyć własne interaktywne opowieści; nie brakuje w nich aluzji literackich, filmowych czy muzycznych w postaci cytatów bądź sentencji. Użytkownicy portalu kolekcjonują nie tylko liczbę znajomych, która staje się wyznacznikiem ich tożsamości. Gromadzą także informacje na temat ulubionych książek, filmów lub muzyki. Tworzą wirtualne wspólnoty fanowskie, gdzie wymieniają się doświadczeniami i wiedzą. Zdaniem cytowanej już Agnieszki Jęczeń „Facebuczanie współuczestniczą w budowaniu estetycznej wyobraźni zbiorowej poprzez tendencje kolekcjonerskie, techniki kształtowania self, wirtualne performance, archiwizację (...) i kulturę dzielenia się”. Z kolei Sherry Turkle $^{36}$ zwraca uwagę, że człowiek na Facebooku może zostać sprowadzony do listy swoich upodobań. Do podobnej refleksji dochodzi Mateusz Halawa, który pisze, że „złożoność osoby jest redukowana do profilu na Facebooku - etyka do estetyki”37. Agnieszka Gromkowska ${ }^{38}$ także podkreśla fakt, że tożsamość człowieka w świecie wirtualnym jest zredukowana do wymiaru mentalnego. Warto jednak zauważyć, że technologie ery Web 2.0 umożliwiają łączenie warstwy werbalnej i wizualnej. W ten sposób następuje zwrot ku cielesności. Zdaniem Łukasza Rogowskiego na wizualności łatwiej jest tworzyć „tożsamość szczegółową, rozproszoną, zbudowaną z części niepozostających ze sobą w związkach"39. Z badań socjologa przeprowadzonych na portalu MySpace wynika, że ludzie najczęściej prezentują swoją osobę za pomocą fotografii. Istotne staje się również „wizualne prezentowanie własnych zainteresowań poprzez eksponowanie ulubionych komiksów czy screenshotów z gier komputerowych" ${ }^{40}$. W przypadku portalu Facebook tego rodzaju obrazy mogą być wybierane jako zdjęcia tła.

${ }_{33}$ M. Jaworska-Witkowska, Ku kulturowej koncepcji pedagogiki, Oficyna Wydawnicza Impuls, Kraków 2009, s. 248.

${ }^{34}$ M. Halawa, Facebook - platforma algorytmicznej towarzyskości i technologia siebie, „Kultura i Społeczeństwo" 2013, nr 4, s. 120.

35 A. Jęczeń, Facebook jako przestrzeń wirtualnej wspólnoty estetycznej, 2013, http://www.kulturaihistoria.umcs.lublin.pl/archives/5047 (dostęp: 3.04.2015).

${ }^{36}$ S. Turkle, dz. cyt., s. 232.

${ }^{37}$ M. Halawa, dz. cyt., s. 121.

38 A. Gromkowska, Tożsamość w cyberprzestrzeni - (re)konstrukcje i (re)prezentacje, „Kultura Współczesna" 1999, nr 3, s. 36.

${ }^{39}$ Ł. Rogowski, O bezcielesności Internetu, [w:] T. Ferenc, K. Olechnicki (red.), Obrazy w sieci. Socjologia i antropologia ikonosfery Internetu, Wydawnictwo Naukowe Uniwersytetu Mikołaja Kopernika, Toruń 2008, s. 68 .

${ }^{40}$ Tamże. 
Zbyszko Melosik ${ }^{41}$ zauważa, że na Facebooku mamy do czynienia z różnymi strategiami autoprezentacji, od idealizacji wizerunku po obnażanie się. Mateusz Halawa $^{42}$ słusznie zaś podkreśla, że sami twórcy serwisu przedstawiają Facebook jako „opowieść o twoim życiu” i „sposób na wyrażenie tego, kim jesteś”. Można powiedzieć, że profil na Facebooku pełni rozmaite funkcje. Z jednej strony jest rodzajem medialnej wizytówki prezentującej naszą osobę, z drugiej narzędziem interakcji - wirtualną tablicą, na której znajomi mogą informować nas o różnych wydarzeniach. Jednocześnie cytowany wcześniej Halawa pisze, że profil na Facebooku przybiera formę osi czasu, na której możemy oznaczać różne wydarzenia ze swojego życia, od ukończenia szkoły po zmianę statusu związku na „to skomplikowane".

Użytkownicy portalu pragną być zauważeni. Mogą nie tylko obserwować, co dzieje się u innych, ale też otrzymywać informację zwrotną o sobie w postaci komentarzy czy lajków odnoszących się do ich aktywności na portalu. Facebook stwarza możliwość „dynamiki kreacji, jest jak gotowy program, w którym możemy rozwijać, obserwować, korygować nasze idealne, wyobrażone »ja«. Projekcja taka może ujawnić silne mechanizmy autoekspresyjne, a czasem ekshibicjonistyczne" ${ }^{43}$. Użytkownik portalu odgrywa rozmaite role społeczne i przybiera różne maski, podobnie jak w codziennym życiu. Autorka podkreśla, że profil na Facebooku „tworzy osoba, która odgrywa niczym w teatrze pewną rolę (awatar), gra w ramach wspólnotowego przedstawienia z góry ustalonymi prawami" ${ }^{4}$.

Zainspirowana rozważaniami teoretycznymi na temat mediów społecznościowych postanowiłam sprawdzić, jak młodzi ludzie traktują swój profil na Facebooku, w jaki sposób go konstruują i czy rzeczywiście traktują go jako rodzaj awatara. W tym celu przeprowadziłam badania jakościowe wśród grupy studentek pedagogiki.

\section{W zwierciadle Facebooka - badania własne}

W trakcie prowadzonych badań posłużyłam się podejściem jakościowym, które stawia akcent na indywidualizację. Tym samym wpisuje się w paradygmat interpretatywny, w którym ważne jest konstruowanie znaczeń oraz sposób odbierania świata przez aktorów społecznych ${ }^{45}$.

Badanie przebiegało $\mathrm{w}$ dwóch etapach. Na początku studenci zostali poproszeni, aby zastanowili się nad wyborem swojego awatara w sieci. Następnie mieli

${ }^{41}$ Z. Melosik, Kultura popularna i tożsamość młodzieży. W niewoli władzy i wolności, Oficyna Wydawnicza Impuls, Kraków 2013, s. 239.

${ }^{42}$ M. Halawa, dz. cyt., s. 119.

${ }_{43}$ A. Jęczeń, dz. cyt.

44 Tamże.

${ }_{45}$ D. Urbaniak-Zając, E. Kos, Badania jakościowe w pedagogice. Wywiad narracyjny i obiektywna hermeneutyka, Wydawnictwo Naukowe PWN, Warszawa 2013, s. 46. 
sporządzić krótki opis wybranej przez siebie postaci. Po przeprowadzeniu jakościowej analizy treści 11 zebranych opisów wyróżniono następujące kategorie awatarów: zoomorficzne, roślinne, postacie ludzkie oraz krajobrazy. Okazało się, że ponad połowa osób wybrała awatary przedstawiające zwierzęta. Pojawiły się: koty, psy, myszy, a nawet małpa czy paw. Tylko jedna osoba wybrała awatar roślinny w postaci róży. Warto podkreślić, że zarówno osoby decydujące się na wybór awatara roślinnego, jak i te preferujące awatara zwierzęcego wymieniały w opisie cechy swojego charakteru. Wyjątkiem był awatar w postaci ptaka. Z opisu wynikało, że wybór pawia miał znaczenie symboliczne, $\mathrm{z}$ jednej strony odnosił się bowiem do poczucia dumy badanej z posiadanych przez nią pasji, z drugiej zaś wskazywał na potrzebę niezależności, o czym świadczą słowa: „przede wszystkim jest ptakiem, a to z kolei zawsze kojarzyło mi się z wolnością, a mi właśnie tej wolności brakuje, wolności wyrażania tego, co czuję, swojego zdania”.

Na uwagę zasługuje fakt, że osoby wybierające krajobrazy jako awatary wskazywały przede wszystkim na swoje cele i pragnienia, rzadziej natomiast pisały o cechach charakteru. Górskie widoki z wodospadem czy wyobrażeniem lasu miały się odnosić do potrzeby wolności, a także transgresji czy pokonywania przeciwności losu. Co ciekawe, tylko dwie spośród 11 badanych osób wybrały postać ludzką. W obu przypadkach awatarom towarzyszyły określone atrybuty. Tak jakby postać człowieka nie była wystarczająca. Jedna z badanych napisała: „Moim awatarem będzie kobieta, która jest wytatuowana i trzyma w rękach duży bukiet czerwonych róż". W przypadku postaci ludzkich akcentowano wygląd zewnętrzny. Znaki na ciele w postaci tatuażu zyskują znaczenie symboliczne. Tatuaż może stanowić przejaw oporu. Jednocześnie kobieta trzyma w dłoniach bukiet róż, co wskazuje na ambiwalencję postaci. Pojawił się także profil ludzkiej twarzy z pejzażem w tle. Ukazanie profilu, a nie całej twarzy podkreśla tajemniczość. Takie wyobrażenia potwierdzają słowa samej badanej, która napisała o sobie, że jest skryta. Ponadto profil kobiety pojawiający się na tle krajobrazu przywodzi na myśl zdjęcie tła na portalu Facebook, które użytkownicy wybierają, konstruując własny profil.

W dalszym etapie badań przeprowadzono zogniskowany wywiad grupowy (badania fokusowe) wśród grupy 11 osób badanych. Wywiad trwał 45 minut, a całość dyskusji została nagrana na dyktafonie. Jak zauważa Stanisław Juszczyk, wywiad fokusowy „służy badaniu wiedzy, opinii, poglądów celowo dobranej grupy osób”46, która zazwyczaj jest niewielka (około 10 uczestników). Zadaniem moderatora jest zachęcanie do interakcji oraz podtrzymywanie dyskusji na wybrany temat. Warto dodać, że osoba prowadząca badania fokusowe może posługiwać się dodatkowymi materiałami stymulującymi (fotografie, fragmenty filmów). Piotr Sztompka sugeruje, że technika wywiadu fotograficznego może być stosowana jako uzupełnienie wywiadów prowadzonych $\mathrm{w}$ grupach fokusowych. $\mathrm{W}$ takim przypadku

${ }^{46}$ S. Juszczyk, Badania jakościowe w naukach społecznych. Szkice metodologiczne, Wydawnictwo Uniwersytetu Śląskiego, Katowice 2013, s. 157. 
„ogniskiem dyskusji stają się właśnie zdjęcia, ich sens oraz odzwierciedlone na nich problemy" ${ }^{47}$. Autor dodaje, że procedura może mieć charakter otwarty, jeśli badacz stawia na „spontaniczne, szerokie skojarzenia dyskutantów”48.

Zachęcona uwagami badaczy zorganizowałam pokaz slajdów ze specjalnie dobranymi fotografiami, które miały pobudzić uczestników do dyskusji. Wśród ilustracji znalazły się między innymi screeny z gier komputerowych The Sims oraz zdjęcia przedstawiające awatary z platformy Second Life. Pojawił się także kadr $\mathrm{z}$ filmu Sala samobójców oraz różne rodzaje awatarów (zoomorficzne, roślinne czy prezentujące sylwetki ludzkie).

Dyskusja rozpoczęła się od pytania: Czy technologie cyfrowe tworzą środowisko dla bycia sobą, czy też sprzyjają zakładaniu wirtualnych masek? Jedna $\mathrm{z}$ respondentek odpowiedziała, że Internet „daje poczucie bezpieczeństwa i przyzwolenie na kreowanie kogoś, kim nie jesteśmy”. Jej zdaniem media cyfrowe sprzyjają zakładaniu masek. Wypowiedź studentki skłoniła do refleksji pozostałych uczestników. Studenci zaczęli się zastanawiać, czym różni się prezentowanie swojej osoby na blogu internetowym od kreacji na portalu społecznościowym. Badani wspólnie doszli do wniosku, że na blogach pokazujemy cząstkę siebie, z kolei na portalach idealizujemy swój wizerunek. Na Facebooku przeważnie umieszcza się zdjęcia, które zostały wcześniej poddane odpowiedniej obróbce. Jedna z badanych zwróciła uwagę, że tam każdy chce pokazać się z jak najlepszej strony, po czym niemal szeptem zwróciła się do koleżanki: „Ty nie masz fejsa, to nie musisz”. Komentarz badanej wskazuje na poczucie przymusu aktualizowania swojego wizerunku. Co ciekawe, studenci byli zgodni co do tego, że blogi mogą być tematyczne, natomiast Facebook to opowieść o sobie, którą generuje sam system, oferując użytkownikom możliwość tagowania, lokalizacji zdjęć czy ustawiania statusów.

Aby zdynamizować dyskusję, pokazano badanym jednominutowy film w postaci animacji poklatkowej (tzw. timelapse), przedstawiający historię życia jednego człowieka od jego narodzin do 50. roku życia. Animacja składała się ze zdjęć $\mathrm{z}$ różnych okresów życia tej samej osoby, które płynnie się zmieniały, pokazując zachodzące zmiany oraz upływ czasu. Tego rodzaju filmy cieszą się ostatnio popularnością. Następnie zadałam pytanie, dlaczego ludzie próbują nadać wizualną formę swojej tożsamości w postaci filmu, fotografii czy bloga. Jedna $\mathrm{z}$ respondentek odpowiedziała, że dzielimy się tym, co uważamy za wartościowe, bo chcemy komuś pomóc albo nawiązać kontakt $\mathrm{z}$ drugim człowiekiem. Powołując się na Małgorzatę Jacyno ${ }^{49}$, w opisywanych badaniach postanowiono wyjaśnić, dlaczego nowe media stają się technikami self. Badani studenci doszli do wniosku, że współczesny człowiek, mimo ciągłego podłączenia do sieci, czuje się samotny i dlatego pragnie zwrócić na siebie uwagę. $Z$ jednej strony oczekujemy informacji na swój temat,

${ }^{47}$ P. Sztompka, Socjologia wizualna. Fotografia jako metoda badawcza, Wydawnictwo Naukowe PWN, Warszawa 2012, s. 69.

48 Tamże.

${ }^{49}$ M. Jacyno, dz. cyt., s. 77. 
a z drugiej sami jesteśmy podglądaczami. Zadano również pytanie, czy selfie staje się symbolem cyfrowego narcyzmu. W tym momencie głos zabrała osoba niepełnosprawna, która do tej pory nie uczestniczyła w dyskusji. Jej wypowiedź wydała mi się interesująca, ponieważ zwróciła uwagę na to, że robienie sobie selfie może być próbą akceptacji samego siebie. Może o tym świadczyć fakt, że niektórzy publikują zdjęcia przedstawiające swoje blizny.

W dalszej części wywiadu poruszono kwestię konstruowania profilu na portalu Facebook. Podjęto próbę zbadania, jakie elementy są istotne w czasie tworzenia osobistego profilu. Na podstawie odpowiedzi badanych studentów wyróżniono następujące kategorie:

- dane bazowe (wiek, płeć, pochodzenie)

- sieć znajomych

- zainteresowania (lista ulubionych książek, filmów, zespołów muzycznych)

- obraz osoby (zdjęcia, awatary).

Badani doszli do wniosku, że użytkownicy portali społecznościowych najczęściej prezentują swoją osobę za pomocą fotografii, przy czym zdjęcia przedstawiają nie tylko konkretnego użytkownika, ale także wybrany kontekst społeczny (sytuacja zabawy, pracy, relacje ze znajomymi). Zdjęcie profilowe przedstawia zazwyczaj sylwetkę internauty, natomiast zdjęcie tła służy do prezentacji zainteresowań tej osoby. Niekiedy odnosi się też do jej przekonań czy cech charakteru. Zapytałam badanych, jak często zmieniają swoje zdjęcia profilowe. Większość osób odpowiedziała, że bardzo rzadko albo wcale nie posiada takich zdjęć. Jednocześnie studenci deklarowali, że mają znajomych, którzy zmieniają zdjęcia trzy-cztery razy dziennie, prosząc o ich komentowanie. Interesującą kwestią pozostawało, co młodzi ludzie chcą zakomunikować otoczeniu, zmieniając często swoje zdjęcia profilowe. Odpowiedzi były różne. Jedni uważali, że chodzi o zdobycie popularności („szykują się na lajki”), inni, że to chęć podkreślenia swojej aktywności oraz informowania otoczenia o tym, co się u nich dzieje (zmiana nastroju, emocji).

$\mathrm{W}$ trakcie podsumowania dyskusji pokazano badanym ilustrację znalezioną w serwisie Demotywatory. Mem przedstawiał człowieka, który zadzwonił do swojego przyjaciela, aby zakomunikować mu, ile kilometrów udało mu się przebiec. Podpis pod zdjęciem sugerował, że mężczyzna zrobił to na wszelki wypadek, gdyby Facebooka wyłączyli, a Endomondo nie zadziałało. Ilustracja wywołała śmiech na sali. Po czym jedna z respondentek powiedziała: „To jest właśnie podsumowanie tego, o czym mówiliśmy: chęć zaznaczenia swojej obecności w świecie. Widzą mnie, więc istnieję". Kiedy na zakończenie zapytałam studentów, jak scharakteryzowaliby tożsamość internetową, jedna z uczestniczek powiedziała, że w przestrzeni sieci mamy do czynienia z kolażem wizerunków. Składamy obraz z fragmentów, przez co nie da się poznać człowieka w pełni. Na to siedząca $\mathrm{z}$ nią $\mathrm{w}$ ławce koleżanka żywo zaprotestowała: „To właśnie w czasie tych godzin spędzonych w Internecie dowiedziałam się o tobie więcej niż w ciągu trzech lat zajęć”. Pokazuje to złożoność problemu. 
W przestrzeni sieci możemy być bliscy i oddaleni, połączeni w samotności. Możemy chować się za awatarami, a tak naprawdę odsłaniać jakąś prawdę o sobie. I na odwrót - możemy stwarzać pozory bliskości, prezentując niemal każdy szczegół ze swojego życia, który został wcześniej odpowiednio wyreżyserowany. Jeśli nastolatka codziennie wstawia swoje selfie z psem na ramieniu, to można odnieść wrażenie, że jest to element autokreacji. Pragnie pokazać siebie jako osobę, która uwielbia psy, a więc jest uczuciowa i wrażliwa. Nawet jeśli zdjęcia nie zostały poddane retuszowi, to i tak możemy mieć do czynienia $\mathrm{z}$ wirtualną maską. Zdarza się, że symboliczna reprezentacja osoby może nam powiedzieć więcej niż seria selfie. Kiedy inna młoda dziewczyna, która zmaga się z otyłością, wybiera na swoje zdjęcie profilowe niedźwiedzia, może to nas odesłać chociażby do mitu o nimfie Kalisto, która została w niego zaklęta. Wydaje się, że celowo nakłada maskę, aby powiedzieć nam coś o sobie. Może to też świadczyć o dystansie wobec własnej osoby. Dla jednych tworzenie awatarów będzie rodzajem ucieczki i przybraniem maski, a dla innych próbą akceptacji siebie. W czasie wyprawy do wirtualnego świata można się zagubić, ale też coś zyskać. Odbyć podróż w głąb siebie i powrócić z niej do świata realnego $\mathrm{z}$ nowymi doświadczeniami.

\section{Zakończenie}

Zaprezentowane $\mathrm{w}$ artykule wyniki badań prowadzonych wśród studentów pokazują, że młodzi ludzie chętnie sięgają po wirtualne maski, konstruując tożsamość internetową. Wybierane awatary często przymują postać symboliczną. Warto się zastanowić, jakie konsekwencje niosą zarysowane w tym artykule zjawiska. Dlaczego młodzi ludzie zakładają wirtualne maski? Czy wynika to z potrzeby uznania i akceptacji? Czy też na wzór celebrytów pragną przeżyć chwilę sławy? We współczesnej kulturze zorientowanej na obrazy wizerunek staje się kluczem do osiągnięcia sukcesu. Liczy się atrakcyjny wygląd, ale i oryginalność. $Z$ tego powodu młodzi ludzie prześcigają się w pomysłach na to, jak przedstawić siebie w najbardziej zaskakujący sposób. W zdjęciach profilowych pojawiają się fotografie własnego cienia czy też ekstremalne selfie (na moście lub klifie). Podejmowane działania mają na celu zdobycie uznania ze strony sieciowego audytorium. Małgorzata Jacyno ${ }^{50} \mathrm{pi}$ sze, że media cyfrowe stają się współcześnie technikami self, a Mateusz Halawa dodaje, iż „korzystanie z Facebooka wiąże się z inskrypcją siebie w formie, która udostępnia Ja nie tylko innym, ale przede wszystkim sobie samemu" ${ }^{\text {"1 }}$. Konstruowanie osobistego profilu na Facebooku daje możliwość przyglądania się sobie. W przypadku osób nieśmiałych i niepewnych własnej wartości może to służyć podniesieniu ich samooceny. $Z$ drugiej strony nadmierne przywiązanie do wizualnych

\footnotetext{
50 M. Jacyno, dz. cyt., s. 77.

51 M. Halawa, dz. cyt., s. 112.
} 
aspektów swojego wizerunku prowadzi do cyfrowego narcyzmu. Może również wskazywać, że w rzeczywistości nie akceptujemy siebie. W tym aspekcie wszelka idealizacja to próba kamuflażu oraz leczenia kompleksów. Młodzi ludzie pragną pokazać się w mediach społecznych z jak najlepszej strony, aby zdobyć sympatię rówieśników. Nieustannie publikują zdjęcia własnej osoby, czekając na komentarze. Kiedy ktoś ich nie otrzyma, czuje się odrzucony. Znane są przypadki samobójstw $\mathrm{z}$ powodu wykluczenia $\mathrm{w}$ mediach społecznych. To ważny problem dla pedagogów i nauczycieli, który nie powinien być bagatelizowany. Trzeba także zauważyć, że przebieranie $\mathrm{w}$ wirtualnej kolekcji masek niesie ryzyko, iż jedna $\mathrm{z}$ nich przyrośnie nam do twarzy. W przestrzeni sieci często mamy do czynienia $z$ kreowaniem fałszywych tożsamości. Człowiek może tworzyć dowolny obraz własnej osoby, korzystając $\mathrm{z}$ dostępnych w sieci elementów. Na forach internetowych często spotykamy awatary osób stanowiące ikony popkultury (ze świata muzyki czy filmu). Być może człowiek ukrywający się za wirtualną maską znanej postaci pragnie w ten sposób zaprezentować swoje zainteresowania i dlatego włącza elementy kultury masowej do własnego wizerunku. Trzeba jednak zachować ostrożność, aby nie zatracić tego, co w nas niepowtarzalne. Współcześnie zaciera się granica między tym, co wirtualne i rzeczywiste. Nowe media przenikają do codziennego życia. Warto z nich umiejętnie korzystać, ponieważ stają się ważnym narzędziem w sztuce autoprezentacji. Już dzisiaj niektórzy pracodawcy traktują osobiste profile na Facebooku jako rodzaj CV. To nasza wirtualna wizytówka, w której liczy się zarówno forma, jak i treść. Nadmierna idealizacja wizerunku może sprawić, że przestaniemy być autentyczni. Dlatego potrzebna jest refleksja oraz zachowanie umiaru.

\section{Bibliografia}

Baudrillard J., Fotografia, czyli świetlny zapis, [w:] M. Boguna-Borowska, P. Sztompka (red.), Fotospołeczeństwo. Antologia tekstów z socjologii wizualnej, Znak, Kraków 2012.

Boholm A., Weneckie widowiska karnawałowe w maskach, przeł. J. Jaworska, [w:] A. Chałupnik, W. Dudzik, M. Kanabrodzki i in. (red.), Antropologia widowisk: zagadnienia i wybór tekstów, Wydawnictwa Uniwersytetu Warszawskiego, Warszawa 2005.

Brückner A., Słownik etymologiczny języka polskiego, Wiedza Powszechna, Warszawa 2000.

Burszta W.J., Tożsamość narracyjna w dobie ekranu, [w:] W. Bolecki, R. Nycz (red.), Narracja i tożsamość. Narracje w kulturze, Instytut Badań Literackich PAN, Warszawa 2004.

Caillois R., Maska i trans, [w:] M. Janion, S. Rosiek (red.), Maski. Transgresje, t. IV, Wydawnictwo Morskie, Gdańsk 1986.

Drosio-Czaplińska J., Barbie versus czajnik, „Ja My, Oni. Co komputer zrobił nam z głową? - Poradnik Psychologiczny „Polityki” 2014, t. 16, nr 9.

Giddens A., Nowoczesność i tożsamość. „Ja” i społeczeństwo w epoce późnej nowoczesności, Wydawnictwo Naukowe PWN, Warszawa 2006.

Gromkowska A., Tożsamość w cyberprzestrzeni - (re)konstrukcje i (re)prezentacje, „Kultura Współczesna” 1999, nr 3, s. 36-49. 
Halawa M., Facebook - platforma algorytmicznej towarzyskości i technologia siebie, „Kultura i Społeczeństwo" 2013, $\mathrm{nr} 4$.

Hopfinger M., Literatura i media po 1989 roku, Oficyna Naukowa, Warszawa 2004.

Jacyno M., Technologie cyfrowe a techniki self, [w:] M. Filiciak, M. Danielewicz, M. Halawa $\mathrm{i}$ in. (red.), Młodzi i media. Nowe media a uczestnictwo w kulturze, SWPS, Warszawa 2010. Jaworska-Witkowska M., Ku kulturowej koncepcji pedagogiki, Oficyna Wydawnicza Impuls, Kraków 2009.

Jęczeń A., Facebook jako przestrzeń wirtualnej wspólnoty estetycznej, 2013, http://www.kulturaihistoria.umcs.lublin.pl/archives/5047 (dostęp: 3.04.2015).

Juszczyk S., Badania jakościowe w naukach społecznych. Szkice metodologiczne, Wydawnictwo Uniwersytetu Śląskiego, Katowice 2013.

Lévi-Strauss C., Maska nie istnieje sama w sobie, [w:] M. Janion, S. Rosiek (red.), Maski. Transgresje, t. IV, Wydawnictwo Morskie, Gdańsk 1986.

Melosik Z., Kultura popularna i tożsamość młodzieży. W niewoli władzy i wolności, Oficyna Wydawnicza Impuls, Kraków 2013.

Ostrowicki M., Tożsamość człowieka $w$ środowisku elektronicznym, „Kwartalnik Filmowy” 2008, nr 62-63.

Rogowski Ł., O bezcielesności Internetu, [w:] T. Ferenc, K. Olechnicki (red.), Obrazy w sieci. Socjologia i antropologia ikonosfery Internetu, Wydawnictwo Naukowe Uniwersytetu Mikołaja Kopernika, Toruń 2008.

Rogowski Ł., Wizualne kształtowanie tożsamości internetowej, http://www.spoleczna.psychologia.pl/lukasz_Rogowski_-_Wizualne_ksztaltowanie_tozsamosci_internetowej.doc (dostęp: 4.05.2015).

Szpunar M., Internet jako pole poszukiwania i konstruowania własnej tożsamości, [w:] E. Hałas, K. Konecki (red.), Konstruowanie jaźni i społeczeństwa. Europejskie warianty interakcjonizmu symbolicznego, Scholar, Warszawa 2005.

Szpunar M., Kultura cyfrowego narcyzmu, Wydawnictwo AGH, Kraków 2016.

Sztompka P., Socjologia wizualna. Fotografia jako metoda badawcza, Wydawnictwo Naukowe PWN, Warszawa 2012.

Turkle S., Samotni razem. Dlaczego oczekujemy więcej od zdobyczy techniki, a mniej od siebie nawzajem, Wydawnictwo Uniwersytetu Jagiellońskiego, Kraków 2013.

Tylikowska A., E-maskacja, „Ja My Oni” - Poradnik Psychologiczny „Polityki” 2014, t. 16, nr 9. Urbaniak-Zając D., Kos E., Badania jakościowe w pedagogice. Wywiad narracyjny i obiektywna hermeneutyka, Wydawnictwo Naukowe PWN, Warszawa 2013. 